\title{
THE EFFECTS OF MACROECONOMIC VARIABLES AND CORPORATE FINANCIAL PERFORMANCE ON STOCK PRICES OF PALM OIL COMPANIES IN INDONESIA
}

\author{
Pebrika Yudha Putri ${ }^{*}$, , Noer Azam Achsani**), and Koes Pranowo***) \\ *) PT GML Performance Consulting \\ Jl. Boulevard Artha Gading No.24-25, North Jakarta City, Jakarta 14240 \\ **) School of Business, IPB University \\ Jl. Raya Pajajaran Bogor 16151 \\ ***) PT. Transocean Maritime
}

Jl. HR Rasuna Said Kav B7 Kuningan, Jakarta Selatan 12910

\begin{abstract}
Palm oil commodity is still one of the largest foreign exchange contributors to the Indonesian states and remains as an attractive industry. In 2016, Indonesia was the main exporter of $\mathrm{CPO}$ with the highest production volume in the world. Palm oil issuers face business challenges from external and internal factors. This research was conducted to analyze whether the stock price of oil palm issuer in Indonesia was influenced by macroeconomic variables (crude oil price, exchange rate, inflation, and interest rate) and financial performance variables (DER, ROA, ROE, EPS, and AUR). This is important because if the macroeconomic variables and financial performance of the company have an impact on the company's performance reflected in the stock price movement of the issuer, this will be an important consideration for investors to take decisions. The results of this research using panel data regression (2010-2016 with quarter data) indicated that only one macroeconomic variable of Exchange Rate that had a negative significant effect on the price of palm oil stock while the financial performance variables in this research affecting the palm oil stock price significantly were DER, ROA, ROE, EPS, EPS t-1, and Stock Price t-1. All variables used in this research can represent the influence of the stock price of palm oil by $99.21 \%$.
\end{abstract}

Keywords: financial performance, oil palm emitents, macroeconomic variables, panel data, stock price

\begin{abstract}
Abstrak: Komoditi kelapa sawit masih menjadi salah satu kontributor devisa terbesar baginegara Indonesia dan menjadi industri yang menarik bagi investor. Tahun 2016 Indonesia merupakan eksportir utama CPO dengan volume produksi tertinggi di dunia (35 juta metrik ton). Dalam industri kelapa sawit, para emiten kelapa sawit menghadapi tantangan usaha baik berupa faktor eksternal dan faktor internal. Penelitian ini bertujuan untuk menganalisis pengaruh fluktuasi variabel makroekonomi (harga minyak mentah/Oil, Kurs, Inflasi, dan Suku Bunga) dan variabel kinerja keuangan (DER,ROA,ROE,EPS,AUR) terhadap harga saham emiten kelapa sawit di Indonesia. Variabel tersebut yang memberikan dampak terhadap prestasi perusahaan tergambar dari pergerakan harga saham emiten akan menjadi bahan pertimbangan bagi investor untuk mengambil keputusan berinvestasi. Penelitian ini menggunakan regresi data panel (data kuartal tahun 2010-2016) dengan hasil menunjukkan bahwa hanya satu variabel makroekonomi yaitu Kurs yang memiliki pengaruh signifikan negatif terhadap harga saham emiten kelapa sawit. Sementara variabel kinerja keuangan dalam penelitian ini yang ditemukan mempengaruhi harga saham emiten kelapa sawit secara signifikan adalah DER, ROA, ROE, EPS, EPS t-1, dan Harga Saham t-1. Seluruh variabel yang digunakan dalam penelitian ini dapat mewakili pengaruh harga saham emiten kelapa sawit sebesar 99,21\%.
\end{abstract}

Kata kunci: kinerja keuangan, emiten kelapa sawit, variabel makroekonomi, data panel,harga saham

\footnotetext{
${ }^{1}$ Corresponding author:

Email: youngfebrika@gmail.com
} 


\section{INTRODUCTION}

The oil palm commodity is still one of the largest contributors to foreign exchange for Indonesian states, where the export value of Indonesian palm oil in 2017 reached US \$ 22.97 billion, increasing approximately by $26 \%$ compared to 2016 of US $\$ 18.22$ billion (GAPKI). The world population in 2017 reached $7,484,325,476$ people with an average growth rate of $1.05 \%$ (UN, Department of Economic and Social Affairs, Population Division, 2013), and this becomes a large market challenge to serve the needs of crude palm oil (CPO). Although in 2016 the average production growth per year ranked the sixth of $9.38 \%$ in the world, Indonesia was still the main exporter of $\mathrm{CPO}$ with the highest production volume with 35 million metric tons in the world (2016 Estimated Data by the United States Department of Agriculture at www.indexmundi.com). In the first semester of 2016, palm oil exports were also the main contributor to Indonesia's trade balance surplus of 3.6 billion US \$ (GAPKI, 2016).

Oil palm companies in Indonesia have faced a great number of challenges in CPO trading in the global market. These challenges are in the form of external factors (macroeconomic variables) and internal factors (such as financial performance variables), companies that have gone public will influence on the movement of the company stock price. Changes in stock prices are an indication of changes in company performance over a period of time. Company achievement is the company ability to manage its assets and certain resources to generate profits (Azhari et al. 2016). Figure 1 shows the movement of the share price of seven palm oil issuers in Indonesia from 2010 to 2016.

Tripathy (2011) conducted a study that showed that there was a correlation between the Indian capital market and macroeconomic variables. Adebiyi et al. (2009) in his research for a case study in Nigeria showed that oil prices negatively affected stock returns, which means that rising oil prices will reduce stock returns in Nigeria.

From 2010 to 2016, the variables of oil, exchange rates, inflation, and interest rates experienced fluctuations in value. Oil prices touched $\$ 36.56$ per barrel at the end of 2015 where the downward trend in oil was followed by a downward trend in world CPO prices at $\$ 520.60$ per metric ton at the end of the same year (indexmundi, 2016). Current world oil prices refer to spot oil prices in US dollars per barrel (159 liters) of WTI (West Texas Intermediate) types traded on the New York Mercantile Exchange (NYMEX) or Brent oil types traded on the Intercontinental Exchange (ICE). Oil traded at West Texas Intermediate (WTI) is high-quality oil. This is because the oil has a low sulfur content and is very suitable for fuel; therefore, this oil price is used as a benchmark for oil trading in the world (Hanafiah, 2015).

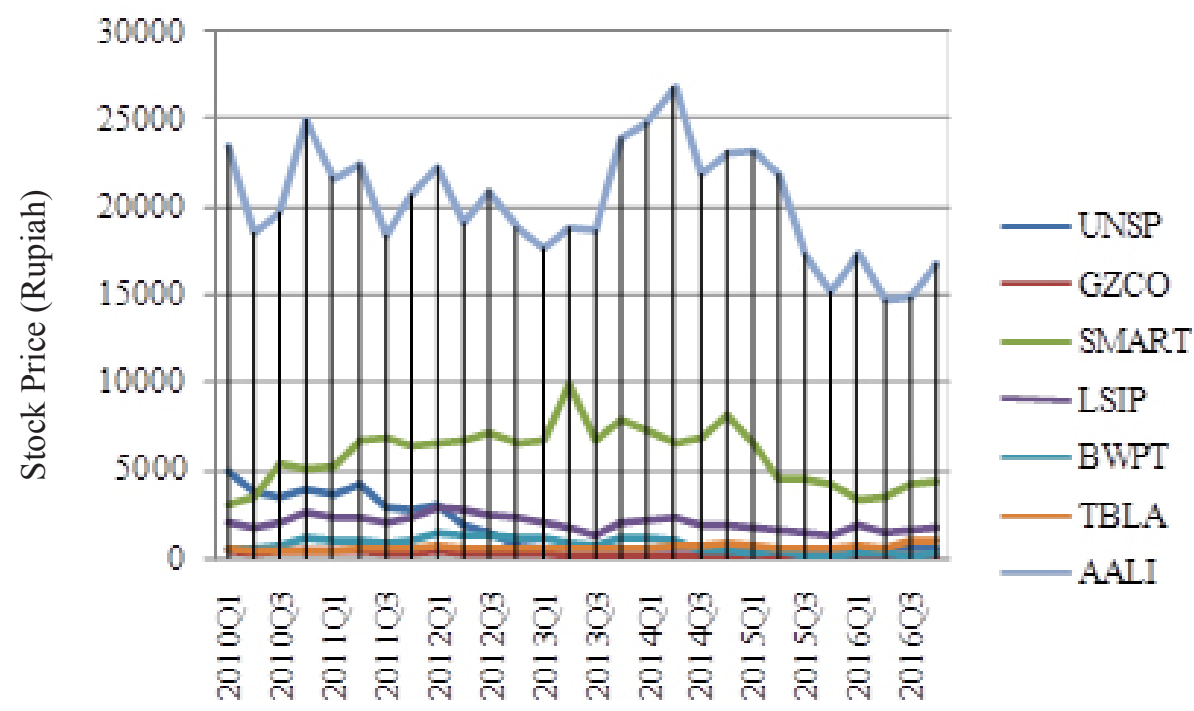

Period (Year and Quarterly)

Figure 1. Chart of stock price movement of seven palm oil issuers in Indonesia 2000-2016 
The exchange rate macroeconomic variable (the exchange rate of the rupiah against the US dollar) also continued to fluctuate in 2010-2016 as evidenced by the weakening of the rupiah exchange rate against the US dollar moving above Rp14,000 per US \$ starting at the end of 2014 (BI, 2016). However, this weakness has been experienced since the end of 2012. According to Sakhowi (2004), the rupiah exchange rate or the rupiah exchange rate against the US dollar has a significant effect on the performance of shares on the IDX.

Increased interestratesarealsooneofthemacroeconomic factors that have an impact on increasing company costs from increasing capital prices. If other factors are considered constant (ceteris paribus), the profitability of the company will decrease. The decline in profits will affect investors' interest in buying the company shares; as a result, the company stock price will decline (Sharif, 2015). According to Rudhi (2016), inflation has a negative and significant effect on the aggregate stock price index in Indonesia, Malaysia, Singapore and the Philippines. The indicator that is often used to measure inflation is the Consumer Price Index (CPI) where changes in CPI over time indicate price movements of goods and services consumed by the public (Dritsaki, 2005). Dirga (2016) conducted a study related to the analysis of the influence of macroeconomic variables on stock prices whose result showed that an inflation factor had a significant positive effect on the return of TBLA. TBLA is one of the issuers sampled in this study.

One factor that can be used by investors to determine stock investment decisions is the internal variable i.e. the company financial performance using financial ratios such as Debt to Equity Ratio (DER), Return On Assets (ROA), Return On Equity (ROE), Earnings per Shares (EPS), and Asset Utilization Ratio (AUR. Both influences of macroeconomic variables and company financial performance on stock prices are equally important to analyze for palm oil issuers because oil palm commodities with $\mathrm{CPO}$ main products are still a mainstay of large foreign exchange-earners for Indonesia.

This research was conducted based a the previous similar study conducted by Dirga (2016) regarding the Analysis of the Effects of Macroeconomic Variables on Stock Prices of Plantation Subsectors. The different thing in this study compared to previous research was the analysis of a combination of external (macroeconomic) and internal (company financial performance) influences as well as the stock price of palm oil issuers by observing data in the period which included conditions in which CPO prices declined along with the decline. The financial performance variable was added to see how the changes in the issuer's financial performance conditions influence it when $\mathrm{CPO}$ prices decline towards stock prices. While the previous research only used external variables, this research was limited to the analysis of the influence of macroeconomic variables (oil prices, exchange rates, inflation, and interest rates) and the company financial performance (DER, ROA, ROE, EPS, and AUR) on listed palm oil issuers from seven listed palm oil issuers listed on the IDX for the period of 2010-2016 using the panel data regression approach. The purpose of this study was to analyze the effect of macroeconomic variables (oil prices, exchange rates, inflation, and interest rates) on listed palm oil stock prices, and the effect of corporate financial performance (DER, ROA, ROE, EPS, and AUR) on issuer stock prices of palm oil.

\section{METHODS}

This research was conducted for one year from December 2016 to December 2017. The data used in this study were secondary data obtained from official websites relevant to the needs of the research including the official websites of seven companies of palm oil issuers, IDX, BI, BPS, and so on. Sample selection was carried out by using purposive sampling method based on the following criteria: The company is engaged in the oil palm commodity plantation sector and is listed as an issuer on the Indonesia Stock Exchange (BEI) at least since 2010 or from previous period to 2016 and so on, which publishes its financial statements every year. Selected companies have the required research data, namely, complete data on quarterly financial statements and stock price data from 2010-2016.

There are seven selected companies: Astra Agro Lestari Tbk (AALI), Eagle High Plantation Tbk (BWPT), Gozco Plantation Tbk (GZCO), PP London Sumatra Indonesia Tbk (LSIP), Sinar Mas Agro Resources \& Tech Tbk (SMAR), Tunas Baru Lampung Tbk (TBLA), and Bakrie Sumatera Plantation Tbk (UNSP). The data in this study were processed using panel data 
regression method. Before the panel data regression was carried out, classical assumption was carried out and the best panel data regression model selection test was conducted to choose the best panel data regression. The hypotheses used in this study were as follows:

H1 : Oil prices do not have a significant effect on the price of palm oil issuers

$\mathrm{H} 2$ : Exchange rates have a significant effect on the price of shares of palm oil issuers

H3 : Inflation does not significantly affects the price of shares of palm oil issuers

H4 : The interest rate does not have a significant effect on the share price of the palm oil issuer

H5 : DER has a significant effect on the share price of palm oil issuers

H6 : ROA has a significant effect on the share price of palm oil issuers

H7 : ROE has a significant effect on the share price of palm oil issuers

H8 : EPS has a significant effect on the price of shares of palm oil issuers

H9 : AUR does not have a significant effect on the price of shares of palm oil issuers

The hypothesis was determined based on previous scientific studies such as Tripathy (2011) who conducted research with the results of a correlation between the Indian capital markets and macroeconomic variables. According to Basher and Sadorsky (2006) stated that the increase in oil prices can affect activities in the capital market, especially the stock market; however, in another study by Maghyereh (2004) using the VAR method provided research results that show that oil prices are not very dominant stock return index in developing countries. This result shows that the movement of oil prices does not always mean the movement of the stock return index. The results of the study also provide a conclusion that capital flows in the stock markets of developing countries are not running effectively due to the influence of speculation from several investors. Rajen and Qiao (1997) used a subset of macroeconomic variables (narrow and broad money supply, nominal and reserve exchange rates of foreign currencies), which are especially relevant in the context of a small open economy, testing for information inefficiencies in the Singapore stock market where the results show that three of the four macro variables co-integrated with stock prices, showing potential inefficiencies in the long run. Aditya et al. (2018) in his research on the Effect of Foreign Exchange Indexes, Macroeconomic Indicators and the Global Economic Crisis on the Composite Stock Price Index in Indonesia found that the BI rate, rupiah exchange rate against the USD and crisis dummy had a significant negative effect on the Composite Stock Price Index (CSPI) in Indonesia. However, the hypothesis of this study only stated that the exchange rate variable had a significant effect, while oil prices, inflation, and interest rates had no significant effects. The main derivative product of the palm oil industry is that cooking oil is a daily consumption item, and despite inflation, rising interest rates, and falling crude oil prices, consumers do not immediately switch to other substitutions which tend to have more expensive prices. The exchange rate has a significant effect because the palm oil export transactions carried out by the issuers use the relevant currency for international trade transactions. Thim et al. (2012) also stated that ROA, ROE, EPS had a significant impact on property stock prices in Malaysia. Hussain (2011) in his study also found results that DER has a relationship with the share price of the cement sector in Pakistan. Meanwhile Haryuningputri (2012) examined the effect of profitability and EVA ratios on the share prices of industrial sectors manufacturing and found that only ROI and EPS had a significant influence on stock prices. Srinivasan (2012) in his research also found EPS had a positive effect on stock prices.

The stock market of the palm oil industry, which is one of the plantation sub-sectors, connects palm oil issuers and investors. This study analyzed the influence of macroeconomic variables and financial performance variables on the stock price of palm oil issuers using panel data regression. Before panel data regression, the classical assumption test was carried out on the research data to find out whether the formulated equations were feasible or not feasible to be analyzed further using panel data regression. Research framework in Figure 6. 


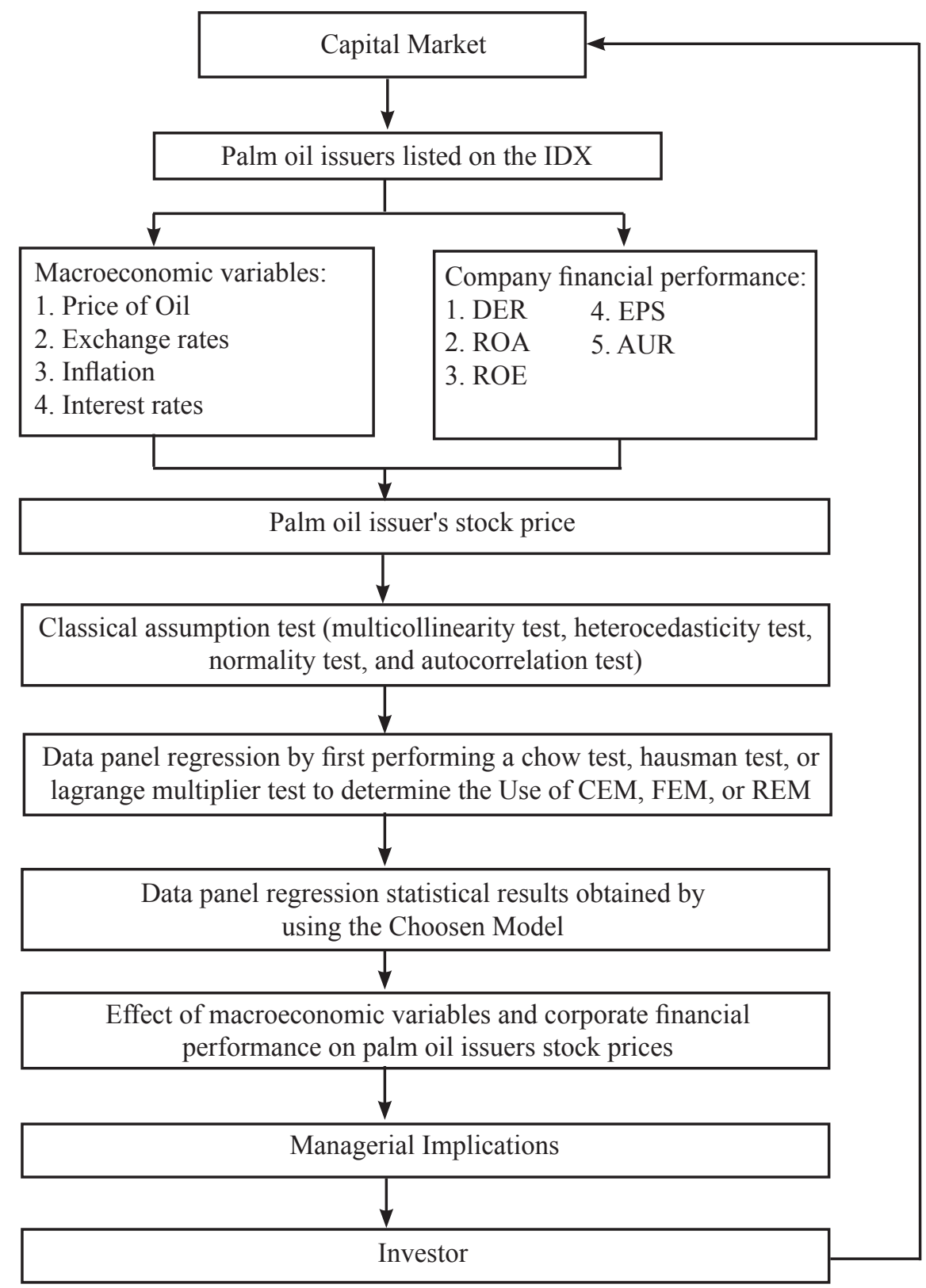

Figure 2. Research framework

\section{RESULTS}

\section{Descriptive statistics}

Descriptive statistical analysis is conducted to see the results of descriptive correlation statistics between variables by using the cross tabulation option in SPSS software. The results of the descriptive statistics obtained are interpreted so that it is known whether certain variables correlate with other variables. Moreover, the results of the Chi Square Test table statistics are obtained where the value of Pearson Chi-Square on Asymp. Sig. (2-sided) can be used to interpret the relationship between two variables i.e. the hypothesis Ho that there is no relationship between variables and Hi hypothesis that there is a relationship between variables. Asymp Value. Sig. (2-sided) is a probability value where if the probability value is $>0.05$ (significance level, $\mathrm{a}=5 \%$ ), Ho is accepted, but if the probability value is $<0.05$, Ho is rejected.

Table 1 is the result of Chi Square Test which shows that only the AUR variable has a correlation with the palm oil issuer stock price which is proven by a value smaller than the $5 \%$ significance level. This means that only the company efficiency ratio of AUR affects the price of shares of palm oil issuers. However, the interpretation of descriptive statistics using SPSS 
software is not yet accurate. Descriptive statistics were conducted manually by looking at the graph of the raw data of each variable whether it has a pattern that is close to or equal to the pattern of chart movements of the palm oil issuer stock prices.

\section{Quantitative Analysis}

Quantitativeanalysisisconductedtoobtainmoreaccurate results of processing statistical data. Classic assumption tests include normality test, heteroscedasticity test, multicollinearity test, and autocorrelation test conducted first to find out whether the equation is feasible or not to be analysed further using panel data regression. The classic assumption test results show that the data in the study passed the normality test, and the data proved to be normally distributed with a probability value of $>$ 0.05 i.e. 0.746619 . Based on the results of scatter plots, the equations passed the heteroscedasticity test because they had scatter plots that did not form a specific pattern. Then the autocorrelation test was conducted by comparing the DW value of the processed data in software e-views with the values of $\mathrm{dL}$ and $\mathrm{dU}$ in the DW table. The processed data showed that the variables used in this study are free from autocorrelation problems because the DW value of the study is 1.524044 . An autocorrelation is free regression equation if the DW value is between -2 to 2 or $-2<\mathrm{DW}<+2$ (Sunyoto, 2009).

Multicollinearity test showed that the AUR variable in the equation in this study experienced multicollinearity problems. Multicollinearity is a condition where there is a strong correlation between the independent variables included in the formation of a regression model, and this violates the rules of data processing using regression because it will reduce the accuracy of the estimation of the research results. The criterion for a variable not affected by multicollinearity is when the variance inflation factor (VIF) value that measures the closeness of the relationship between the independent variables of a variable is not more than 10 . However, the AUR variable in this study had a VIF value of 55,103. The steps that can be taken to overcome this problem were by removing the AUR variable from equation (1) so that a new equation is formed which is equation (2) with no AUR variable.

$$
\begin{aligned}
& \mathrm{Y}=\mathrm{a}+\mathrm{b}_{1} \text { LN_OIL }+\mathrm{b}_{2} \text { LN_KURS }+\mathrm{b}_{3} \text { INFLASI }+ \\
& \mathrm{b}_{4} \mathrm{SB}+\mathrm{b}_{5} \mathrm{DER}+\mathrm{b}_{6} \mathrm{ROA}+\mathrm{b}_{7} \mathrm{ROE}+\mathrm{b}_{8} \mathrm{EPS}+ \\
& \mathrm{b}_{9} \mathrm{AUR}+\mathrm{e} \quad(1) \\
& \mathrm{Y}=\mathrm{a}+\mathrm{b}_{1} \text { LN_OIL }+\mathrm{b}_{2} \text { LN_KURS }+\mathrm{b}_{3} \text { INFLASI }+ \\
& \mathrm{b}_{4} \mathrm{SB}+\mathrm{b}_{5} \mathrm{DER}+\mathrm{b}_{6} \mathrm{ROA}+\mathrm{b}_{7} \mathrm{ROE}+\mathrm{b} 8 \mathrm{EPS} \\
& + \text { b}_{9} \text { LN_SAHAM(1) }+\mathrm{b}_{10} \text { LN_OIL(1) + } \\
& \mathrm{b}_{11} \text { LN_KURS }(1)+\mathrm{b}_{12} \operatorname{DER}(1)+\mathrm{b}_{13} \mathrm{ROA}(1)+ \\
& \mathrm{b}_{14} \operatorname{ROE}(1)+\mathrm{b}_{15} \operatorname{EPS}(1)+\mathrm{e}
\end{aligned}
$$

Where: Y (Palm Oil Issuer's Stock Price (in Logarithms)); a (Intercept); bi (i = 1, 2, 3 ... etc.) ( Slope coefficient);LN_OIL (Price of Oil (in Logarithms)); LN_KURS (Exchange (in Logarithms));INFLATION (Inflation); SB (Interest Rate); DER (Debt to Equity Ratio); ROA (Return on Asset); ROE (Return on Equity); EPS (Earnings per Share); AUR (Asset Utilization Ratio); LN_SAHAM (1) (Stock Price t-1 (in Logarithms)); LN_OIL (1) (Price of Oil t-1 (in Logarithms)); LN_KURS (1) (Exchange rate t-1 (in Logarithms)); DER (1) (Debt to Equity Ratio t-1 (DER)); ROA (1) (Return on Asset t-1); ROE (1) (Return on Equity t-1); EPS (1) (Earnings per Share t-1); e (Error or Component error).

Table 1 Correlation probability values of each variable with price palm oil issuer shares.

\begin{tabular}{lcc}
\hline \multicolumn{1}{c}{ Variabel } & Asym. Sig. (2-sided) & Correlation with palm oil issuer's stock price \\
\hline OIL & 0.514 & uncorrelated \\
KURS & 0.514 & uncorrelated \\
INFLASI & 0.431 & uncorrelated \\
SB & 0.345 & uncorrelated \\
DER & 0.258 & uncorrelated \\
ROA & 0.251 & uncorrelated \\
ROE & 0.251 & uncorrelated \\
EPS & 0.250 & uncorrelated \\
AUR & 0.021 & Correlated \\
\hline
\end{tabular}

*foreign exchange rate 
The classic assumption test was carried out again and showed that the research data passed all the classic assumption tests. Panel data regression was then performed to obtain statistical results, but the results of the initial panel data regression data showed the $\mathrm{R}$-square result was $29.35 \%$ which means that the independent variables were macroeconomic variables and financial performance variables could only explain the palm oil issuer stock price of $29.35 \%$ with the results that the variables that significantly affected the stock price of palm oil issuers included DER, ROA, ROE, and EPS. Based on this, this study added several lag variables including LN_STOCK (1), LN_OIL (1), LN KURS (1), DER (1), ROA (1), ROE (1), and EPS (1). Lag variable is a variable that represents the previous condition ( $\mathrm{t}-1)$ of the related variable and is used to capture the potential unanalyzed effect of variables on the previous conditions on the current condition. For example, the value of the company financial ratios where the data used can be ascertained is the latest data of the previous year which potentially not represents the value of the related variables well due to the long period of time while the current conditions had changed a lot. The results of panel data regression processing based on equation (2) are presented in Table 2.

The addition of the seven lag variables completed the equation (2) which was no longer used the AUR variable. The results in Table 2 show that the addition of the lag variable increased the R-square value of the statistical results significantly by $99.21 \%$. This shows that all independent variables used in this study can represent the picture of its effect on the stock price of palm oil issuers amounting to $99.21 \%$, while the remaining less than $0.79 \%$ was explained by other variables outside of this study.

Table 2. Statistical results of data panel regression equations (2)

\begin{tabular}{|c|c|c|c|c|}
\hline Variable & Coefficient & Std. Error & t-Statistic & Prob. \\
\hline $\mathrm{C}$ & 7.674199 & 4.489202 & 1.709480 & 0.0892 \\
\hline LN OIL & -0.087481 & 0.093693 & -0.933697 & 0.3518 \\
\hline LN KURS & -0.612404 & 0.232362 & -2.635564 & 0.0092 \\
\hline INFLASI & 1.312577 & 1.138224 & 1.153180 & 0.2505 \\
\hline SB & 2.538501 & 3.050749 & 0.832091 & 0.4065 \\
\hline DER & -0.180169 & 0.009253 & -19.47213 & 0.0000 \\
\hline ROA & -0.070505 & 0.035212 & -2.002307 & 0.0469 \\
\hline ROE & 0.047467 & 0.022776 & 2.084059 & 0.0387 \\
\hline EPS & $-3.59 \mathrm{E}-05$ & $1.61 \mathrm{E}-05$ & -2.222373 & 0.0276 \\
\hline LN_SAHAM(1) & 0.567340 & 0.092318 & 6.145501 & 0.0000 \\
\hline LN OIL(1) & -0.018768 & 0.091015 & -0.206212 & 0.8369 \\
\hline LN KURS(1) & 0.286989 & 0.242261 & 1.184625 & 0.2378 \\
\hline $\operatorname{DER}(1)$ & -0.021863 & 0.012365 & -1.768098 & 0.0789 \\
\hline ROA(1) & -0.002489 & 0.057165 & -0.043536 & 0.9653 \\
\hline ROE(1) & -0.018632 & 0.033089 & -0.563074 & 0.5741 \\
\hline $\operatorname{EPS}(1)$ & $7.14 \mathrm{E}-05$ & $2.53 \mathrm{E}-05$ & 2.816173 & 0.0054 \\
\hline \multicolumn{5}{|c|}{ Weighted Statistics } \\
\hline R-squared & 0.992136 & \multicolumn{2}{|c|}{ Mean dependent var } & 41.85093 \\
\hline Adjusted R-squared & 0.991147 & \multicolumn{2}{|c|}{ S.D. dependent var } & 22.26259 \\
\hline S.E. of regression & 1.042277 & \multicolumn{2}{|c|}{ Sum squared resid } & 181.4191 \\
\hline F-statistic & 1003.299 & \multicolumn{2}{|c|}{ Durbin-Watson stat } & 1.524044 \\
\hline Prob(F-statistic) & 0.000000 & & & \\
\hline
\end{tabular}




\section{Effects of Macroeconomic Variables (Oil Prices, Exchange Rates, Inflation, and Interest Rates) on Palm Oil Issuer Stock Prices}

The results of the study in Table 2 show only one macroeconomic variable, namely Kurs or foreign exchange rate, which significantly affected the stock price of palm oil issuers. Exchange Rate variable had a coefficient value of -0.612404 and a probability value of 0.0092 which means that the Exchange Rate variable had a significant negative effect on the stock price of palm oil issuers. If the exchange rate of the rupiah against the US dollar increases, the share price of the palm oil issuer will decline, and vice versa. It should be understood that if the value of the rupiah exchange rate against the US dollar increases, it will indicate that the rupiah exchange rate weakens against the US dollar; conversely, if the value of the rupiah exchange rate against the US dollar declines, it will indicate that the rupiah exchange rate strengthens against the US dollar. These results support the results of Tripathi and Seth's (2014) study that there is a significant correlation between capital market indicators and macroeconomic factors.

Meanwhile, other macroeconomic variables in this study of Oil, Inflation, SB, Oil (t-1) and Exchange Rate (t-1) were found not to have significant effects on the price of shares of palm oil issuers. For oil variable, for example, the results of the research showed that oil did not affect the stock price of palm oil issuers in accordance with the results of the research by Maghyereh (2004) using the VAR method in which it shows that oil prices do not influence the stock return index in developing countries. Inflation is proven not to affect the price of palm oil issuers in Indonesia, indicating that increasing prices in general, such as prices of factors of production, do not have a significant effect on changes in the price of oil palm stocks. Likewise the SB variable or interest rate is not found to affect the price of oil palm shares; thus, if the government raises or decreases interest rates, the policy does not significantly cause changes in the price of shares of palm oil issuers. The price of Oil and the exchange rate of the previous period are also proven not to significantly affect the price of the shares of the issuers of palm oil. Then the historical data on Oil prices and Exchange rates cannot be used as the main reference for analyzing changes in stock prices of palm oil issuers.

\section{Effect of Company Financial Performance (DER, ROA, ROE, EPS, and AUR) on Palm Oil Issuer Stock Prices}

The results of the research in Table 2 show that there are six financial performance variables in this study that have significant influences on the price of the shares of palm oil issuers, namely, the DER, ROA, ROE, EPS, EPS (t-1), and Stock Prices (t-1 ). The DER variable had a coefficient value of -0.180169 and a probability value of 0.0000 which means that the DER variable had a significant negative effect on the price of the shares of the palm oil issuer. Debt to Equity Ratio (DER) shows the capital structure of a company which is a comparison between total debt and equity used as a source of corporate funding. If the value of the debt ratio increases, the share price of the palm oil issuer will decrease, and vice versa. The increased debt ratio indicates that the company is increasingly unable to maximize capital management to pay its debt.

The ROA variable had a coefficient value of -0.070505 with a probability value of 0.0469 which indicates that the ROA variable had a negative significant effect on the price of the palm oil issuer. Financial performance variable ROA measures a company ability to obtain net income for the total assets owned by the company and indicates that the company uses all available assets well or not. In this study, it was found that if the ROA value increased, the share price of the palm oil issuer would decrease, and vice versa. Please note that the total assets of a company consist of Liabilities (Debt or loan) and Equity (owner deposit and retained earnings). The composition of assets dominated by debt has the potential to bring risks to investors compared to the composition of assets dominated by equity. Therefore, a high ROA cannot be ascertained indicating a good company to be an investment choice.

ROE variable had a coefficient value of 0.047467 with a probability value of 0.0387 which indicates that the ROE variable had a significant positive effect on the price of the shares of the palm oil issuer. If the ROE value increases, the share price of the palm oil issuer will also increase and vice versa. ROE is the ratio of net income to common stock equity to measure the rate of return on investment in shareholders. Increased ROE shows the ability of company management to manage its existing equity to get better net income. EPS variable with a coefficient value of $-3.59 \mathrm{E}-05$ had a probability value of 0.0276 which indicates that the 
EPS variable had a significant and negative effect on the stock price of palm oil issuers. If the value of EPS increases, the stock price will decline, while if the EPS value decreases, the share price of the palm oil issuer will increase. EPS financial performance variable is a ratio that shows the level of profit per share obtained by shareholders which are ideally expected to be of high value. However, a high EPS value can be caused by the number of outstanding shares being reduced so that it cannot be used as a benchmark in assessing the quality of stock investments.

EPS t-1 variable had a coefficient value of 7.14E05 with a probability value of 0.0054 , and the stock price variable $t-1$ had a coefficient of 0.567340 with a probability value of 0.0000 , which means that the two lag variables both significantly and positively influenced the share price of coconut issuers of palm oil. If the EPS value and stock price $\mathrm{t}-1$ decrease, the share price of the palm oil issuer will also decrease, whereas if the EPS value and stock price $\mathrm{t}-1$ increase, the current share price of the palm oil issuer will also increase, indicating that the share price of the palm oil issuer is influenced by the EPS value and stock price in the previous period.

\section{Managerial Implications}

In accordance with the results of the research, when the exchange rate of the rupiah against the US dollar increases (the rupiah weakened), the share price of the palm oil issuer will decline. In terms of origin, both domestic and foreign investors have different behaviors in decision making. Foreign investors will need more rupiahs to return capital per one US dollar. Foreign investors tend to hold back investments or withdraw their capital back to their home countries. For company management, efforts need to be made to manage the company shareholding by domestic investors because the risk of returning the capital is lower than that of foreign investors. Meanwhile, the government can make efforts to manage the risk of exchange rate fluctuations by issuing fiscal policies and monetary policies.

Hussain (2011) in his research entitled Impact of the Capital in the Stock Price of the sector in Pakistan cement found that the higher the DER value, the lower the company income. The increase in DER value on the results of this study negatively affects stock prices resulting in the decrease in issuer price of palm oil and showing that the company is increasingly unable to maximize capital management to pay its debt. The step needed by the company management is managing the company equity to continue to grow so that at least the break-even point can finance the company debt.

In this study, it was found that the increasing value of ROA had a negative significant effect, reducing the price of shares of palm oil issuers. The high ROA value in the palm oil industry needs to be considered because the oil palm industry companies are industries with a large asset character but are generally obtained through debts. Therefore, investors need to analyze the sources of assets of companies in the palm oil industry. From the issuer side, it is necessary to improve asset management and source of its acquisition to strengthen the company financial independence without having risks of debts. ROE measures the ability of a company management to manage equity to obtain net income. The higher the ROE of a company, the better the company will manage its management (Keown et al. 2008). The results showed an increase in the value of ROE directly proportional to the increase in stock prices (significantly positive). Based on the results of the research, company management needs to maintain and improve the composition of the company own capital to empower the company independence in generating profits.

EPS illustrates the amount of rupiah earned for each ordinary share and becomes a factor for the company leadership to decide the amount of dividends to be distributed to shareholders. One of the goals of investors in buying shares is to obtain dividends or capital gains. High EPS will encourage increased investor expectations for company performance and rising stock prices. However, the results of the study show that higher values of EPS will have a significant negative effect on the stock price of palm oil issuers where the stock price will decrease if the EPS value increases. This can happen because investors do not just pay attention to the value of earnings per share to make a decision to buy or not buy shares in the company concerned, because basically the value of EPS can increase if the number of shares outstanding is reduced. Therefore, issuers need to strive to increase the value of EPS which really comes from the increase in the company revenue. 
The EPS t-1 variable actually has a significant positive effect on the price of palm oil issuers. This shows that investors can see the condition of past EPS values to determine the purchase decision of the current palm oil issuers. If the value of EPS t-1 increases, the share price of palm oil issuers will increase and vice versa. Therefore, it is important for the management of the company to maintain the value of EPS in the previous period to increase to be a consideration of investors in seeing the current stock price movements and making decisions to invest. Likewise, the share price variable t-1 has a significant positive effect on the current share price of the palm oil issuer. This signals the company management that investors pay attention to past data on stock prices when deciding to invest in palm oil issuers. Therefore, the company management in addition to paying attention to the condition of the exchange rate, must manage various internal factors such as the financial performance through the DER, ROA, ROE, EPS, EPS t-1 ratio, and t-1 stock prices according to the movement of the influence of each variable of the price of the stock issuer of palm oil so that a good stock price is formed at the $t$ time.

\section{CONCLUSIONS AND RECOMMENDATIONS}

\section{Conclusions}

The occurrence of fluctuations in macroeconomic variables beyond the control of various parties in the palm oil industry to be something that should be anticipated weighs the likely impact on the price of the shares of the palm oil issuer itself. If the company achievements are affected by fluctuations in macroeconomic variables and changes in the company financial performance, the issuer stock price movements will be a benchmark for investors to decide whether or not to invest in palm oil issuers so that analyzing macroeconomic variables and deciding which financial performance variables actually have a significant influence on the share price of palm oil issuers are important to be conducted.

The results showed that of the four macroeconomic variables used of oil prices, exchange rates, inflation, and interest rates, it was proven that only the exchange rate variable had a negative significant effect on the price of shares of palm oil issuers while the financial performance variables in this study of DER, ROA, ROE, EPS, EPS $t-1$, and $t-1$ Stock Prices were found to significantly affect the price of the shares of palm oil issuers. Therefore, company management needs to apply strategic management to manage the value of DER, ROA, ROE, EPS, EPS t-1, and Stock Price t-1 according to the results of research to well maintain the stock price of palm oil issuers and even increase the prices. Meanwhile for the rupiah exchange rate against the US dollar, government assistance is required to take monetary and fiscal policy measures so that they do not become highly risky for the company as a driver of the economy.

\section{Recommendations}

Both investors and palm oil issuers are advised to be better able to anticipate fluctuations in the exchange rate, DER, ROA, ROE, EPS, EPS t- 1 and t- 1 Stock Prices related to the impact on palm oil issuer stock prices. For investors, an analysis of the fluctuations of the seven variables is required for additional considerations or investments. As for issuers, the fluctuations in the seven variables need to be managed by the issuers themselves and with government assistance so as not to have a negative impact on company performance and stock price movements. For further research related to this research, it is suggested that other variables be more capable of describing the true condition of the company such as the Debt Service Coverage Ratio (DSCR) and add other tools such as depth interview management of oil palm companies and oil palm stock players so that they obtain more factual information on the condition of the oil palm industry from the perpetrators.

\section{REFERENCES}

Adebiyi MA, Adenuga AO, Abeng MO, Omanukwue PN. 2009. Oil price shocks, exchange rate and stock market behaviour: empirical evidence from Nigeria. Research Paper Central Bank of Nigeria $1-41$

Aditya, Sinaga BM, Maulana ATB. 2018. Pengaruh indeks bursa luarnegeri, indikator makroekonomi dan krisis ekonomi global terhadap indeks harga saham gabungan di Indonesia. Jurnal Aplikasi Bisnis dan Manajemen 4(2): 284-295. https:// doi.org/10.17358/jabm.4.2.284.

Azhari DF, Rahayu SM, Zaharoh ZA. 2016. Pengaruh ROE, DER, TATO, dan PER terhadap harga saham perusahaan properti dan real estate yang go public di Bursa Efek Indonesia. Jurnal Administrasi Bisnis (JAB) 32(2): 1-5. 
Basher SA, Sadorsky P. 2006. Oil price risk and emerging stock markets. Global Finance Journal 17(2): 224-251. https://doi.org/10.1016/j. gfj.2006.04.001.

[BI] Bank Indonesia. 2016. Data Nilai Tukar Rupiah Terhadap Dolar Amerika Serikat Tahun 20102015. Jakarta: Bank Indonesia.

[BPS] Badan Pusat Statistik. 2016. Total Ekspor Minyak Kelapa Sawit Indonesia Tahun 20002015. Jakarta: Badan Pusat Statistik.

Dirga SP. 2016. Analisis pengaruh variabel makroekonomi terhadap return kelompok saham subsektor perkebunan. Jurnal Aplikasi Manajemen 14(3):595-607. https://doi. org/10.18202/jam23026332.14.3.20.

Dritsaki. 2005. Linkage between stock market and macroeconomic fundamentals: case study of Athens Stock Exchange. Journal of Financial Management \& Analysis 18(1): 38-47.

Hanafiah MS. 2015. Pengaruh harga minyak dunia, nilai tukar rupiah terhadap dollar, dan tingkat inflasi terhadap harga saham. Jurnal Administrasi Bisnis 28(2):1-7.

Haryuningputri M. 2012. Pengaruh rasio profitabilitas dan EVA terhadap harga saham pada sub sektor industri manufaktur di BEI. Diponegoro Journal of Management 1(2): 67-79.

Hussain NM. 2011. Impact of capital structure on stock price of cement sector in Pakistan. Interdisciplinary Journal of Contemporary Research in Business 3(3): 778-798.

[IM] Index Mundi. 2016. Palm oil production growth by country in $1000 \mathrm{MT}$. https://www.indexmundi. com [2017 Januari 01].

Keown AJ, Martin JD, Petty JW, Scott DF. 2008. Dasar-Dasar Manajemen Keuangan. Widodo M, penerjemah; Indriani, editor. Jakarta: Indeks. Terjemahan dari: Financial Management: Principal and Applications.

Maghyereh A. 2004. Oil price shocks and emerging stock markets: a generalized VAR approach.
International Journal of Applied Econometrics and Quantitative Studies 1(2): 27-40.

Rajen M, Qiao Y. 1997. Macroeconomic variables and stock prices in a small open economy: the case of Singapore. Pacific-Basin Finance Journal 5(3): 377-388. https://doi.org/10.1016/S0927538X(96)00029-7.

Rudhi WS. 2016. Analisis Pengaruh Variabel Makroekonomi terhadap Indeks Harga Saham Agregat di Kawasan Asia Tenggara (Studi Komparasi Pada 5 Negara ASEAN Periode 2001-2015) [tesis]. Semarang: Universitas Diponegoro.

Sakhowi A. 2004. Analisis perubahan kurs rupiah, inflasi dan suku bunga terhadap kinerja saham. Jurnal Ekonomi dan Bisnis 2(1): 1-16.

Syarif MM. 2015. Pengaruh indikator makroekonomi dan faktor global terhadap indeks harga saham gabungan (IHSG). Jurnal Studi Manajemen Universitas Negeri Surabaya 9(2):1-15.

Srinivasan P. 2012. Determinants of equity share prices in India: a panel data approach. The Romanian Journal 15(46): 205-228.

Thim KC, Choong YV, Asri NQB. 2012. Stock performance of the property sector in Malaysia. Journal of Modern Accounting and Auditing. 8(2): 241-246.

Tripathy N. 2011. Causal relationship between macroeconomic indicators and stock market in India. Asian Journal of Finance and Accounting 3(1): 208-226. https://doi.org/10.5296/ajfa. v3i1.633.

Tripathi V, Seth R. 2014. Stock market performance and macroeconomic factors: the study of Indian equity market. Global Business Review 15(2):291-316. https://doi.org/10.1177/0972150914523599.

[UN] United Nation. 2016. World Population Prospects: The 2012. https://esa.un.org/unpd/wpp/ publications/Files/WPP2012_HIGHLIGHTS. pdf [2017 Januari 01]. 